\title{
EFFECT OF DOLOMITE LIME ON SOIL MATRIC SUCTION
}

\author{
M.I.S. Fazlina1, Putera Agung Maha Agung', Saiful Azhar Ahmad Tajudin',3, \\ Z. M. Nizam ${ }^{3}$, Mustaffa A. Ahmad ${ }^{3}$, Muhammad Fathur Rouf Hasan ${ }^{2}$ \\ ${ }^{1}$ GeoStructure \& Rehabilitation Centre, Universiti Tun Hussein Onn Malaysia, Batu \\ Pahat Johor, 86400, Malaysia
}

${ }^{2}$ Civil Engineering Department, Politeknik Negeri Jakarta, Depok, 16424, Indonesia

${ }^{3}$ Faculty of Civil Engineering and Built Environment, Universiti Tun Hussein Onn Malaysia, Batu Pahat Johor, 86400, Malaysia

e-mail:misfazlina@uthm.edu.myll,putera.agungmagung@sipil.pnj.ac.id ${ }^{2}$

\begin{abstract}
The most fundamental of unsaturated soil is matric suction parameter. Matric suction in unsaturated soils plays an important role in controlling physical and mechanical properties. This parameter can influence some other important parameters of soil, such as effective stress, shear strength, swelling pressure, etc. Investigation of matric suction was performed on Ayer Hitam soil, at Batu Pahat District, Johor, Malaysia. Field monitoring works were conducted with and without dolomite treatment at the slopes of Ayer Hitam acidic soil. Field testing used some devices to find out the behavior of matric suction during the rainy session. The result shows that the soil matric suction with dolomite treatment is larger than without treatment and matric suction has a significant difference around $20-50$ kPa. Enhancement of acidity from the dolomite treatment was not only decreasing pores size caused by the alternating of the microstructure of soil but also leading to increasing the matric suction. The treatment of dolomite material is able to control matric suction and increase the stability of slope acidic Ayer Hitam soil.
\end{abstract}

Keywords: Acidic Soil; Dolomite; Matric Suction; Slope Stability; Unsaturated soil

\section{INTRODUCTION}

Chemical stabilization using lime treatment is not only widely applied for type of soil, such as improvement of soil behavior when a dry and rainy session, but also enhances the workability during construction of soil and, or foundation works (Al-Swaidani et al., 2016; Tran et al., 2014; Azhar et al., 2016; Lu and Zhang, 2019).

However, the recent studies reported that lime stabilization can significantly affect to some parameters of unsaturated soil layers when subject to drying and wetting process, especially for matric suction or negative capillary pressure or $\left(u_{a}-u_{w}\right)$ of soil (Russo and Modoni, 2013; Stoltz et al., 2014). Some investigations even found that the lime treatment can alternate the soil-water system at unsaturated soil layers during the cycle of climate change or dry and rainy sessions. In microanalysis, the alternating of cation-exchanges will induce flocculation soil particles. It is finally not only modifying water retention capacity, but also matric suction. In most cases, this matter will influence to shallow foundation system embedded at unsaturated soil layers which near the soil surface, especially for the soil bearing capacity of the foundation.

This research aims to make a field study model to measure soil matric suction range with and without dolomite material during the cycle of climate change at Ayer Hitam, Batu Pahat District, 
Malaysia, such as temperature variation and, or drying and wetting process, etc.

\section{METHODS}

\section{Soil sample and devices}

Some previous studies were investigated by Azhar et al. (2016); Fazlina et al. (2018; 2019); and Ismail et al. (2018). Site model investigation was applied to this research. The field sample testing model is shown in Figure 1. Acidic soil samples of the Ayer Hitam area were used in this study. Physical properties were tested at the soil mechanic laboratory. Each sample was prepared and differentiated by soil moisture content. The nature of physical soil properties is shown in Table 1. Site model testing used prismatic quadrilateral with $1.5 \mathrm{~m}$ height and 4 (four) slopes were used for this study. The size of base prismatic model was square-shaped with each side $5.0 \mathrm{~m}$ with the slope gradient designed was about $30^{\circ}$. Each slope used a variation of water content and was treated with and without dolomite material.

From four slopes, one slope was not treated with dolomite material (signed by SMSA), and three slopes were treated with dolomite material (signed by SMSB, SMSC, and SMSD). Soil moisture content values were significantly different at the upper, middle, and lower parts of the slope. The upper and middle were less than the lower parts.

Intensity and duration of rainfall were measured by Data-Logging Rain Gauge Watermark 1120 . The rain gauge was installed at the top of the mound model. Instrumentation of Watermark Soil Moisture Sensor by using program SpecWare 9 Basic was installed at $1.0 \mathrm{~m}$ from the top of mound model to each slope direction to determine the soil matric suction. The sensor could monitor and measure matric suction up to 200
$\mathrm{kPa}$. The sensor was installed at $20 \mathrm{~cm}$ depth on the slope surface. The device was completed by a data logger and recording device to collect observation data.

\section{Dolomite material}

Soil samples used in this research were mixed with dolomite material to increase the acidity of the soil $(\mathrm{pH})$, because the soil $\mathrm{pH}$ was only around 3 . In the study, it was only SMSA used the original value of soil $\mathrm{pH}$, and the other of each surface of slope (SMSB, SMSC, and SMSD) was treated by $2.1 \mathrm{~kg}$ with a covered area of $4.4 \mathrm{~m}^{2}$. Table 2 shows soil $\mathrm{pH}$ value measured $1.0 \mathrm{~m}$ depth from the top of the site model.

\section{Observation work}

Soil matric suction was collected by the device of sensor data. Data of intensity and duration of rainfall were also noted by the data acquisition system. Data reading from field measurements was collected around 3 (three) months. Figure 2 shows the changes in matric suction during the rainy session. Data reading was taken every week and observation was performed during the summer and rainy seasons.

\section{RESULTS AND DISCUSSION}

From some observation, all soil samples of the site model investigated were classified as moderate to strong acidity (Fazlina et al., 2019), as shown in Tabel 2. Slope surface without dolomite treatment (SMSA) has a soil matric suction value lower than SMSB, SMSC, and SMSD) or treated by dolomite. The investigation result of this research was almost the same as the study result from Rosone et al. (2016).

The range of rainfall duration normally was 10 to 60 minutes. The highest intensity was $46.2 \mathrm{~mm} / \mathrm{hr}$. Table 3 shows the summary of the intensity of natural 
rainfall during the field monitoring. Figure 2 shows matric suction decreases during heavy rainfall closing to the range of $30-100 \mathrm{kPa}$. This matter indicates that the water required the time any longer to infiltrate at the slope during the wetting process in the rainy season.

From the 4 (four) slopes observed, the matric suction has a significant difference around $20-50 \mathrm{kPa}$. Changes in matric suction will be depended on soil density and moisture water content (Chen, 2018). It can be explained that after dolomite was added to the soil-water system. The addition of dolomite is not only produced several reactions, such as cationexchanges, flocculation process, carbonation, and pozzolanic reactions but also leads to improvement of soil properties actually. However, the cationexchanges are more react than the others. During the reaction, all ions of dolomite will raise the attraction of cationexchanges from clay particles. The effect of cation-exchanges of clay particles and attraction caused by dolomite ions become closing to each other and generate flocculation process. This flocculation will fulfill the pore volume and number of pores become decrease, finally, it will enlarge of matric-suction of soil. The flocculation process that occurred by this study is supported by some studies from Rahman (2103); Ghobadi et al., (2014); Samantasinghar, (2014); and Elsharief et al. (2015). Soil stiffness and shear strength increase as an impact of the increasing matric suction according to some studies from Zhang et al., (2015).

Danh et al. (2014) concluded that there was not intra-aggregate micro pores size change after the addition of dolomite, it was only occurred an increasing temperature of micropore structure caused by pozzolanic reactions (Azhar et al., 2016). However, this research actually shows the opposite results, the addition of dolomite material into acidic Ayer Hitam soil creates decreasing micro pores size and increasing the matric suction to enlarge the soil stiffness and shear strength. Finally, all slopes become stable.

\section{CONCLUSION}

Acidic soil Ayer Hitam treated by dolomite material significantly will create a flocculation process to decrease the size of the micro pores and leads to an increase in matric suction. The flocculation process is generated as an effect of attraction of cation-exchanges of clay soil particles and dolomite ions in acidic soil. Soil acidity value will be corrected by dolomite material. The slope treated by dolomite material treatment is more stable than without treatment. Matric suction is very dependent on volumetric moisture content and the number of pores. The time rate level of increasing matric suction with dolomite material in wet conditions is slower than in dry conditions.

\section{ACKNOWLEDGEMENT}

The authors would like to acknowledge the Ministry of Higher Education and Universiti Tun Hussein Onn, Malaysia, and Civil Engineering Department of Politeknik Negeri Jakarta (or State Polytechnic of Jakarta) for supporting and collaborating works to finish this research work and publishing this paper.

\section{REFERENCES}

Al-Swaidani, A., Hammoud, I., \& Meziab, A. (2016). Effect of adding natural pozzolana on geotechnical properties of lime-stabilized clayey soil. Journal of Rock Mechanics and Geotechnical Engineering, 8(5), 714-725. 
Azhar, A. T. S., Azim, M. A. M., Aziman, M., \& Nabila, A. T. A. (2016). Leachability of Arsenic (As) Contaminated Landfill Soil Stabilised by Cement and Bagasse Ash. In IOP Conference Series: Materials Science and Engineering, 160(1) 012078.

Azhar, A. T. S., Fazlina, M. I. S., Aziman, M., Fairus, Y. M., Azman, K., \& Hazreek, Z. A. M. (2016). Preliminary Analysis on Matric Suction for Barren Soil. In IOP Conference Series: Materials Science and Engineering, 160(1), 012052.

Chen, Y. (2018). Soil Water Retention Curves Derived as a Function of Soil Dry Density. GeoHazards, 1(1), 319.

Elsharief, A. M., Abdelaziz, O. A. and Dafalla, M. A. (2015). The Influence of Matric Suction on the Shear Strength of Highly Plastic Compacted Swelling Clays. Electronic Journal of geotechnical Engineering, 20(25), 12555-12568.

Fazlina, M. I. S., Azhar, A. T. S. \& Aziman. M. (2018). Design, Operation and Construction of a Large Rainfall Simulator for the Field Study on Acidic Barren Slope. Civil Engineering Journal. Vol. 4(8), 1851-1857.

Fazlina, M. I. S., Azhar, A. T. S., \& Aziman, M. (2019). Evaluating Coefficient of Uniformity for Rainfall Simulation Study. Journal of Applied Geoscience and Built Environment, 1(1), 1-5.

Ghobadi, M. H., Abdilor, Y., \& Babazadeh, R. (2014). Stabilization of clay soils using lime and effect of $\mathrm{pH}$ variations on shear strength parameters. Bulletin of Engineering Geology and the Environment, 73(2), 611-619.

Ismail, M. A. M., Hamzah, N. H., Min, N. S., Abidin, M. H. Z., Tajudin, S. A.
A., \& Madun, A. (2018). Analysis of Infiltration-Suction Response in Unsaturated Residual Soil Slope in Gelugor, Penang. In Journal of Physics: Conference Series, 995(1), 012052.

Lu, N., \& Zhang, C. (2019). Soil sorptive potential: Concept, theory, and verification. Journal of Geotechnical and Geoenvironmental Engineering, 145(4), 04019006.

Rahman, M. T. (2013). Evaluation of Moisture, Suction Effects and Durability Performance of Lime Stabilized Clayey Subgrade Soils. University of New Mexico: Master Thesis.

Rosone, M., Farulla, C. A., Ferrari, A., Torta, C., \& Celauro, C. (2016). Suction controlled drying and wetting cycle effects on the volumetric behaviour of a limetreated high plasticity clay. In E3S Web of Conferences, 9, 14020. EDP Sciences.

Stoltz, G., Cuisinier, O., \& Masrouri, F. (2014). Weathering of a lime-treated clayey soil by drying and wetting cycles. Engineering Geology, 181, 281-289.

Samantasinghar, S. (2014). Geoengineering properties of lime treated plastic soils. National Institute of Technology Orissa, India: Master's Thesis.

Tran, T. D., Cui, Y. J., Tang, A. M., Audiguier, M., \& Cojean, R. (2014). Effects of lime treatment on the microstructure and hydraulic conductivity of Héricourt clay. Journal of Rock Mechanics and Geotechnical Engineering, 6(5), 399-404.

Zhang, X., Mavroulidou, M., \& Gunn, M. J. (2015). Mechanical properties and behaviour of a partially saturated lime-treated, high plasticity clay. Engineering Geology, 193, 320-336. 


\section{Appendix}

Table 1. Soil properties (Fazlina et al., 2018)

\begin{tabular}{cc}
\hline Composition & Value \\
\hline Moisture content $(\%)$ & 28 \\
Permeability $(\mathrm{m} / \mathrm{s})$ & $7.45 \times 10^{-7}$ \\
Bulk density, $\rho b\left(\mathrm{Mg} / \mathrm{m}^{3}\right)$ & 1.517 \\
Dry density, $\rho d\left(\mathrm{Mg} / \mathrm{m}^{3}\right)$ & 1.426 \\
Specific gravity, Gs & 2.70 \\
Liquid Limit, LL & 46 \\
Plastic Limit, PL & 27 \\
Plasticity Index, PI & 19 \\
Void Ratio,e & 0.756 \\
Porosity,n & 0.431 \\
Dry unit weight, $\gamma d\left(\mathrm{kN} / \mathrm{m}^{3}\right)$ & 15.08 \\
Saturated unit weight, $\gamma s a t\left(\mathrm{kN} / \mathrm{m}^{3}\right)$ & 19.3 \\
\hline
\end{tabular}


Applied Research on Civil Engineering and Environment (ARCEE) VOL. 03 NO. 01, August 2021

Table 2. $\mathrm{pH}$ value of soil

\begin{tabular}{ccc}
\hline Slope & pH value & Average \\
\hline \multirow{3}{*}{ A } & 3.1 & \\
& 3.0 & 3.1 \\
& 3.2 & \\
B & 5.2 & 5.1 \\
& 5.1 & \\
& 5.1 & 5.2 \\
C & 5.2 & \\
& 5.3 & \\
& 5.2 & 5.2 \\
D & 5.1 & \\
& 5.2 & \\
\hline
\end{tabular}


Table 3. Rainfall intensity (Fazlina et al., 2019)

\begin{tabular}{cccc}
\hline Date & $\begin{array}{c}\text { Duration } \\
(\mathbf{m i n})\end{array}$ & $\begin{array}{c}\text { Total Rainfall } \\
(\mathbf{m m})\end{array}$ & $\begin{array}{c}\text { Intensity } \\
(\mathbf{m m} / \mathbf{h r})\end{array}$ \\
\hline $29 / 6 /$ & 58 & 26.8 & 27.7 \\
$3 / 7 /$ & 49 & 14.7 & 18.0 \\
$8 / 7 /$ & 31 & 6.1 & 11.8 \\
$9 / 7 /$ & 15 & 6 & 24.0 \\
$11 / 7 /$ & 33 & 11.1 & 20.2 \\
$12 / 7 /$ & 60 & 25.3 & 25.3 \\
$14 / 7 /$ & 37 & 6.1 & 9.9 \\
$28 / 7 /$ & 10 & 7.7 & 46.2 \\
\hline
\end{tabular}




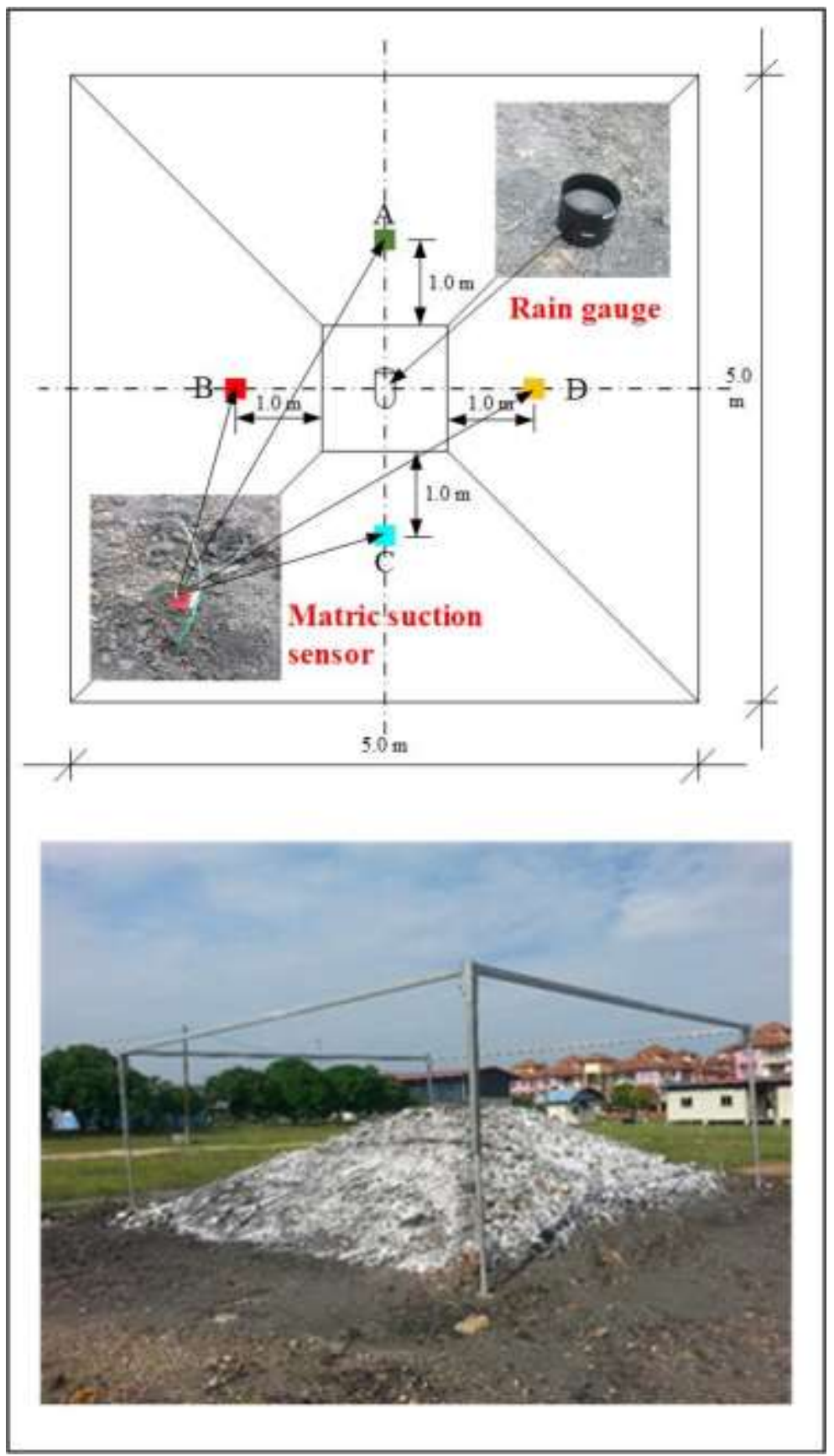

Figure 1. Instrument positions (matric suction sensor and rain gauge) 


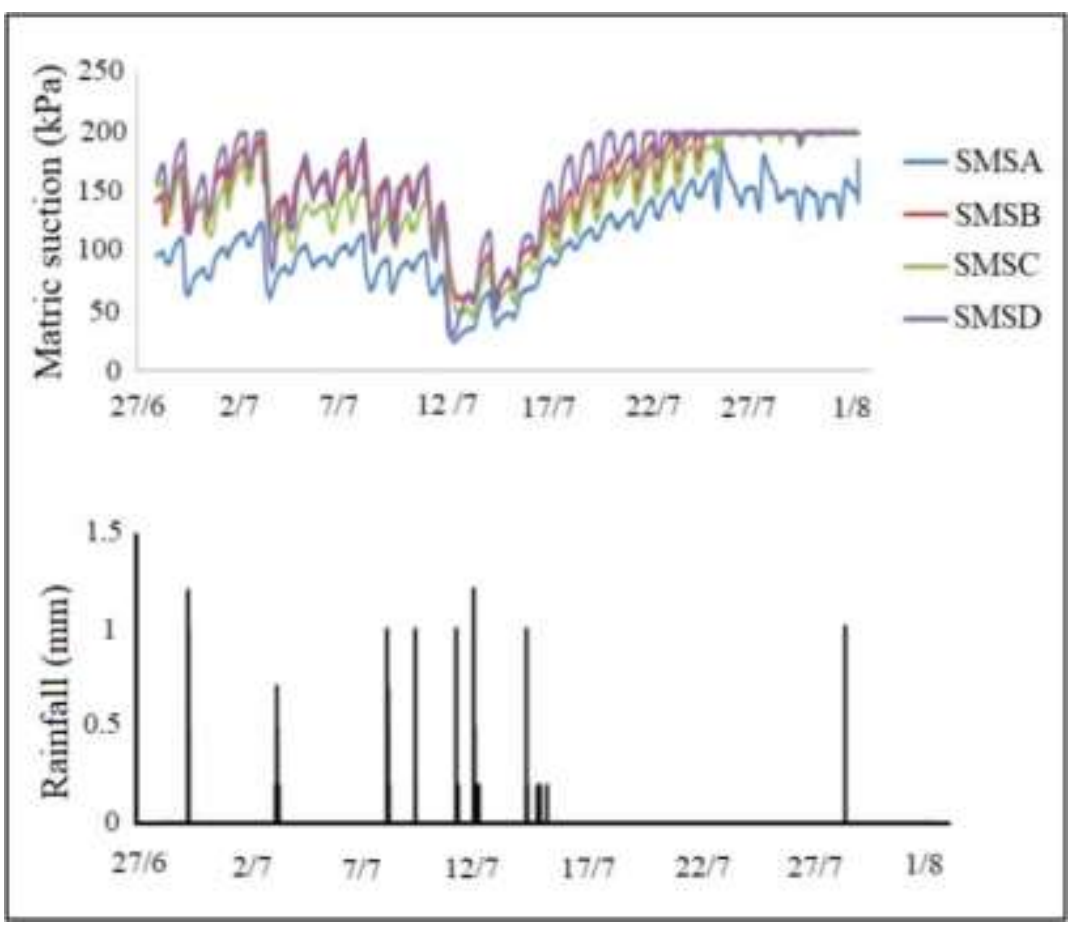

Figure 2. Matric suction \& rainfall versus time (Fazlina et al., 2019) 